\title{
Tarzan as a cultural prism: Ideological Associations in Edgar Rice Burroughs's Tarzan of the Apes
}

\author{
Nora Hadi Q. Alseed \\ Asst. Professor of English \& Vice Dean \\ College of Administrative \& Humanities Sciences \\ Al Jouf University, Sakaka \\ Kingdom of Saudi Arabia \\ Cell no.: +966553399720Ｅ-mail: norapoetry74@hotmail.com
}

Received: 22-02-2013

doi:10.7575/aiac.ijalel.v.2n.3p.120
Accepted: 22-03-2013

Published: 01-05-2013

URL: http://dx.doi.org/10.7575/aiac.ijalel.v.2n.3p.120

\begin{abstract}
More than any other of Burroughs' many creations, Tarzan has become a staple of popular culture. The character functions as a cultural prism, in which the concerns, anxieties, desires, and tastes of particular times and places are encapsulated in such a way to make us look at that context in a different perspective. Burroughs' original Tarzan embodies several of the aspirations, tensions, and failings of the early twentieth-century Unites States. On one hand, the novel refracts a national longing for an unspoiled nature, on another hand, the novel echoes the racism and violence directed at African Americans at this time.
\end{abstract}

Keywords: Edgar bourrough, American culture, African American ecoboding

Among the creations of Edgar Rice Burroughs' Tarzan was considered to be the most promoted cultural aspect. In 1918 , the first version of the novel was developed into motion pictures was estimated to be the first film in popular cinema that had a profit of over one million dollars. In 1930, apart from being made into a film Tarzan was also considered to be a radio show. It was also initiated as the first serial dramatic show along with "Buck Rogers in $25^{\text {th }}$ Century". Both the shows were introduced on the same day in January 1929. With the development of twentieth century, Tarzan was determined to present better attraction through television, comic books, cartoons, songs, and lunchboxes and even in certain maps. Burroughs bought a ranch and named it after his invention, Tarzan. This was later developed into a town of Tarzan, California. Twenty six books regarding Tarzan have been published by Burroughs whose trend was then followed and published by both authorized and unauthorized authors.

Tarzan as a character is quite smooth and sneaky than one would think. Burroughs assumed Tarzan to be raised by anthropoid apes who was orphaned at the shores of equatorial western Africa. Following this he was portrayed as a character who was more or less an international gentleman spy. The storyline then shifted to him being briefly replaced by his son followed by an exploration of the underworld in a completely different novel of Burroughs'. Also certain other authors have worked with different versions of Tarzan. The other versions of Tarzan also worked with the same concept of him being raised in Africa by apes and different to the civilization. There exit a difference between Burroughs original version of Tarzan and other versions of Tarzan created by various other authors. The main difference between the original version and other cultural descendents of Tarzan can be identified from the well known clipped speech pattern which has been promoted in the films. However towards the end of the original novel, Tarzan speaks perfect English and French and had taught himself to read and write English.

In order to determine how the characteristic functions with respect to cultural prism are presented, the concerns, anxieties, desires and tastes of particular times and places are summarized in a manner which enables the reader identify with the views of Tarzan in a better context. In the original novel of Bourroghs Tarzan was depicted as a character of Twentieth century United States who was determined to embed all the characteristics, tensions, failings and aspirations similar to the original version as created by Burroughs in first novel. Due to the isolation of Lord and Lady Greystoke by group of aggressive mutineers, the rightful successor of Lord Greystoke was orphaned in equatorial western Africa and was apparently raised by apes in the jungle.

Tarzan struggled to survive and balance his heredity with his upbringing resulting in the development of a god like specimen of humanity. This resulted in Tarzan identifying with "civilized" members of his own species as weak and stupid. Tarzan is found to be a character that is found to sing the blues when it comes to the "progress" of modern civilization which he considers to be anti-progress.

The novel has been written at the same time when US government was establishing lands for national parks and the Audubon Society. The novel thus presented the groundwork for the nation's need for unspoiled nature which may save the country from corruption and decadence of the new urban lifestyle which was aimed at more urbanization. The National Audubon society was determined to be an American nonprofit environmental organization that has been established for conservation. Audubon was established in 1905 and makes use of science education and support from 
grassroots communities in order to accomplish its mission of conservation. Audubon education considered the conservation of nature centers and wildlife sanctuaries to be important and create awareness among people regarding wildlife and techniques to promote this conservation. There also exists certain center of Audubon till date that creates awareness to people with regards to the need to preserve wildlife and natural world. Audubon's Hog Island Camp in Maine celebrated its $75^{\text {th }}$ anniversary in August 2011.

The concept of Tarzan is considered to be gendered. By means of Tarzan an attempt to reframe the masculinity that was determined to be fading in Victorian era particularly in the nineteenth and certain period of twentieth century where the concept of "gentleman" was promoted widely in literature.

The novel is considered to be illustration for Nature Child archetype. The relation between nature and animal is beautifully portrayed by Tarzan. The novel brings forth the primal nature of Tarzan by portraying him as a man who is more attuned to his animal instincts rather than conforming to human social norms. Burroughs represents a feral child from literature in order to illustrate the Nature Child archetype. Tarzan has been raised by apes in the jungle thus preventing him from the corruption and weakness of humans. As the novel progresses it is observed how Tarzan was unable to tolerate the ways of humans and wanted to avoid the human world and preferred being one with nature again.

By means of comparing Tarzan and his cousin who has taken the title of Tarzan unknowingly, Burroughs tries to argue the explicit between nature and manliness. As soon as Tarzan saw first human, see cooked meat. Tarzan, who does not have the practice of cooking the meat, was motivated to gulp large quantity of raw meat at a time and bury the rest of meat beside the trailer which he could collect while returning. By means of wiping his thighs with hi greasy fingers Lord Greystoke took the trail of Kulonga, the son of Mbonga. Simultaneously at the same time another Lord Greystoke, younger brother of original Lord Greystoke's father sent his chops back to club's chef as they were underdone. As soon as completing his repast, he dipped his finger ends into the silver bowl of scented water and used snowy damask for drying them. The literature also compares the human nature of Tarzan when he kills Sabor, the lioness. Here the savage nature of Tarzan is highlighted most effectively.

These illustrations may demonstrate an eco bonding sensitivity. Eco bonding was defined by Clinebell to be the oneness an individual feels with respect to the entire biosphere, "the positive inner and outer sense of interdependence with the whole biosphere" (60). He adds that: The Ecological Circle: Nurturing nature with caring and respect depends on bonding with nature and thus being nurtured by nature. Ecological spirituality is the integrating power of this interdependent process of healing people and healing the earth, or vice versa. (182)

According to Charles Pinches, eco bonding is defined to be the process of discovering, befriending and intentionally developing individual's philosophical rootedness in the life giving biosphere. The aspects involved in the Eco bonding involves claiming and enjoying one's nurturing, energizing, life enhancing connection with nature.

The relation between Tarzan, natural world, and manliness are considered to be one of most important underlying themes associated with his portrayal throughout the novel. Yi-Fu Tuan an eco- psychologist has demonstrated the need for back to nature movements which has corresponding cultural relations with the portrayal of Tarzan. The interaction process between human and non-human worlds is presented beautifully in literature. Attempts have been made in order to respond to the modern detachment between them by means of eco-psychological desire "to create place and to value place". Tuan detailed in his book of Space and Place: the Perspective of Experience that "'[s]pace' is more abstract than 'place"'. With the help of the quote of "enclosed and humanized space is place" space and place have been distinguished by Tuan [54]. Tuan has differentiated between space and place and determined that the two concepts are independent. The honesty, freedom and threats of space can be determined from the place and vice versa. Furthermore, if we think of space as one which allows movement, then place is pause; each pause in movement makes it possible for location to be transformed into place (6).

Through the entire novel of Tarzan of the Apes there is an observation made with regards to the idea that the male in the society play a vital role in supporting and protecting the weaker population. Tarzan was brought up along with the tribe and adopted into it because of his gorilla mother Kala. As the book progresses it can be seen the growth of Tarzan adapting to the ape culture. For example right at the beginning of the novel it can be seen that Tarzan was found to have a hard time to adapt to jungle conditions and was a vulnerable part of the tribe during battle. Tarzan did not have the physical strength and stamina to climb trees or swing across the jungle as fast as the other gorillas which slowed down the rest of the gorillas. This made him somewhat of a misfit, an outsider. However he was considered as one of their own and was given help whenever required. Burroughs proves the theme of male protection and superiority with Tarzan multiple times throughout the book (Anon., 1999).

The central cultural association with respect to original Tarzan was determined to be associated with cruelty and destructiveness. . The novel and the film have focused on aspects related to manliness as a factor but also identifies with "white supremacist" manliness which has been least flirted with in the Anglo-Saxon literature in the past. Burroughs identified that in ape language Tarzan means "white skin". He has also been described as one who describes himself to the first outsiders he views as a man who has killed a number of black men. Thus the work of Tarzan can be identified to be one which was in line with the works presented during the time of violence against African Americans. Right before the novel was published, The National Association for the Advancement of Colored People (NAACP) was established.

In 1910, NAACP was established as an organization which was found to have concern for mobilization with respect to racial justice. The organization was formed based upon the discussions and meetings conducted between black and 
white intellectuals, business persons, educators and professionals who are having concern for formation of NAACP. The main objective of the organization was to fight of the racial inequity African Americans. The languages used by Burroughs in Tarzan of the apes demonstrate the racism which was highlighted by these organizations during their course of work.

There are a wide range of examples presented in the study by Burroughs with regards to highlighting of racism. Burroughs refers blacks to be "sleek and hideous", (60) and describes them to be "bestial brutishness due to their appearance" (57) he considers blacks to be terrible, "fearful creatures" (60). According to Burroughs blacks are not humans they are wild beasts and consider them to be fools. Tarzan has no awareness of superstition and he is fearless (69). At the same time blacks are assumed to be highly superstitious. In similar manner Burroughs demonstrated blacks to be "awe-struck" due to the vanishing offerings provided by them to Tarzan. He makes their religion seem silly and makes them seem foolish. Readers consider the blacks to be fools believing in false god when compared to the intelligence of Tarzan. It can be declared from the languages used by Burroughs that blacks are terrible and stupid beasts. They are not considered as humans rather they are treated as other animals in the jungle.

Even during the portrayal of Tarzan perspective, racism has also been highly promoted in the book. According to Tarzan blacks are just fools and he is better when compared to them. The first experience of Tarzan with black man was when his ape mother Kala was killed by a black man. Later Tarzan noticed a black man hitting another black man which made him to think about the cruelty among his own race. Tarzan has noticed that most of the animals in the jungle do not harm their prey while this was absent among his own race. However this observation has been made only with black men. He has also noted that black men "were crueler than his own apes, and as savage and cruel as Sabor" (72). The concern expressed by Tarzan with regards to black men was only to certain extent. Tarzan had little to no feelings when blacks are killed by Mbonga and at the same time he was worried and furious when Mbonga kills white people. When Mbonga tribe makes an attempt to kill whites it has been considered in a completely different view by Tarzan. Tarzan is portrayed to be a character who is only concerned with the safety of whites rather than blacks. Tarzan is not presented to be a character that has a friendly relationship with black men. When D'Amot and Tarzan noticed some black people clearing the forest, the first thing that came into the mind of Tarzan is to kill them.

Similar to Heart of Darkness by Conrad, Tarzan of Apes was considered to be demonstrating African Americans as a group of people who are substandard to whites. Conrad makes an attempt to sympathize with the blacks in his literature but presents blacks to be people who are completely lost creatures who are not able to fend themselves. However in comparison it can be observed that racism has been given much more purposeful importance in the Tarzan of the Apes. Burroughs in his novel demonstrates and identifies with black people to be more revolting, barbaric people by the way the characters build through the novel. The language used by Burroughs is considered to present an undertone of racism throughout the novel. Also the opinions of Tarzan regarding the black men may result in the creation of an atmosphere which makes the reader to hate them and consider them to be substandard to white people. The objective of Burroughs may not to be publish a book on racism but in the Tarzan of the Apes the one aspect which highlights itself is racism which has been given a great deal of importance.

This is not an attempt to justify the choice of racist characteristics but given explanation with regards to expression of characters in the novels of Burroughs. The behavior of the hero of the novel is presented in a manner which provides the foundation for and fights against his assumptions with respect to the modern popular personification of the prototype of a hero. In the novel, Burroughs presents Tarzan as an ideological shell into which various different historical specifications has been recorded and identified with. Though he starts off as a character that is uncivilized, his artistic bent identifies his vices as presented by humans who are "civilized". The assumptions made by Burroughs for presenting the character of Tarzan are found to change during the course of several years of writing. The first novel does consider and gives much importance to the racist stereotypes. However thought the course of which work Burroughs has given arguments with respect to imperialism.

Tarzan has been symbolized to be a noble savage. The "savage"” form of Tarzan can be identified due to the completely uncivilized upbringing among apes with the sole purpose of survival in the jungle. It can be observed from the beginning of the novel that Tarzan was quite adept at speaking ape very effectively and with training could do everything they could do in an effective manner. Despite his initial struggle to develop his physical stamina Tarzan eventually developed skills of becoming a hunter who would do well in battle as much as any of the other apes. He proved himself to be a very skillful hunter and a fighter. In the novel it can be seen that Tarzan becomes the King after killing the king of apes. Tarzan is also portrayed to seek vengeance with the Negroes tribe after his ape mother Kala was killed.

At this juncture Tarzan was identified to be a complete savage by the tribe that it did not even strike them that he could be human. The Negro tribe truly believed that he was an evil spirit who was out to destroy them. When Tarzan rescues Jane and Paul D'Arnot there is a much higher comparison of the how much Tarzan could be a savage. This is because this is where there is a direct comparison between civilized and uncivilized humans. To any human brought up normally Tarzan maybe considered to be the ultimate definition of savage. However the noble nature of Tarzan is also symbolized by his efforts to defend his tribe, save the explorers and his ability to fall in love with Jane.

In his quest to reunite with Jane Tarzan travels across the world leaving behind all he knows and becomes disappointed when he finds out that Jane was married to William Clayton. Even after finding out that the wealth that Clayton possessed was rightfully his Tarzan did not choose to take the estate from the couple. He showed his nobility in not wanting to disrupt the happy life of the couple and wanted happiness for Jane. This may be considered to be an 
extremely noble act as most "civilized" people would have taken the wealth which was rightfully theirs. Thus the idealism of Tarzan being a Nobel savage has been clearly observed through the novel (Anon., 1999).

It can be declared that Tarzan being a cultural memory is not able to break away from his historical origin. By means of long series published over decades and wider considerations with regards to popular culture, the character has been determined to be demonstrating the characteristics of various periods and places. Tarzan has also presented views with regards to certain environmental issues such as illegal hunters as identified in the film of Tarzan and Trappers in the year 1958. While considering Tarzan in terms of both novel and film, he has been supporting the international political chaos that includes fighting for WWII and battling communists during Cold War. In the film Tarzan Triumphs of 1943, Johnny Weissmuller thrashes Nazis who assaults jungle after uttering the dialog of "Now, Tarzan makes war!" The film was released two years later after the entrance of America into the war. The film has been determined to be providing comedic misinformation, with Tarzan's vigorous manliness towards corrupted civilians. At the end of the movie, Tarzan's Chimp, Cheeta who has not been represented in the novel manages to contact a unit of Nazi through radio due to which a German officer mistakes Cheeta to be Hitler.

The readers of Tarzan from North America and all over the world can consider it to be the prism of culture that reflects local tradition as it builds up across generations. At the same time other readers may experience the development of different versions of Tarzan with respect to pop culture perfections. In such cases Tarzan can escape from the context and get adapted into other environmental situations. One has to satisfy and agree to the archetype of Tarzan as an individual who was orphaned and raised by anthropoid apes.

\section{References}

Anon. (1999). eNote. Retrieved 5 May 2012 from http://www.enotes.com/tarzan-apes-qn/themes-characters.

Bleiler, E. F. (1982). Edgar Rice Burroughs. In Bleiler (Ed.), Science Fiction Writers. New York: Charles Scribner's Sons.

Barlow, S. (2012). Personality Test: The Nature Child Archetype | Suite101.com. Retrieved 5 May 2012 from http://susanna-barlow.suite101.com/personality-test-the-nature-child-archetype-a357604\#ixzz1tHQuGfbk.

Essoe, G. (1968). Tarzan of the Movies. New York: Cadillac.

Fortres, P., \& Clinebell, H. (1996). Ecotherapy: Healing Ourselves, Healing the Earth. Minneapolis, MN: Fortress.

Graham, F., \& Knopf, A. (1990). The Audubon Ark: A History of the National Audubon Society. New York: Alfred Holtsmark.

Erling, B. (1986). Edgar Rice Burroughs. Boston: Twayne.

Haslam, J. (2011). He had become my Tarzan. Retrieved from http://www.openlettersmonthly.com/he-had-become-mytarzan/Online.

Lupoff, R. (1968). Edgar Rice Burroughs: Master of Adventure, New York: Ace.

Porges, I. (1975). Edgar Rice Burroughs: The Man Who Created Tarzan. Provo, UT: Brigham Young University Press.

Tuan, Y. (2002). Space and Place: The Perspective of Experience. Minneapolis: University of Minnesota.

Holtsmark, E. B. (1981). Tarzan and Tradition: Classical Myth in Popular Literature. Westport, C. T.: Greenwood Press. 